\title{
Algılanan Okul Etkililiği Ölçeği’nin Geliştirilmesi: Geçerlik ve Güvenirlik Çalışması ${ }^{1}$
}

\section{Development of Perceived School Effectiveness Scale: Validity and Reliability Study}

\author{
Dürdane Lafc1-TOR ${ }^{2}$, Emine YAVUZ
}

• Geliş Tarihi: 23.07.2019 • Kabul Tarihi: 30.12.2019 • Çevrimiçi Yayın Tarihi: 30.12.2019

\section{$\ddot{O} \mathbf{z}$}

$\mathrm{Bu}$ çalışmada, öğrenci algılarına göre okul etkililiğinin belirlenmesinde geçerli ve güvenilir ölçümler sağlayacak bir ölçek geliştirilmesi amaçlanmıştır. Bu bağlamda ölçekten elde edilen ölçümlerin geçerlik ve güvenirlik kanıtları toplanmış ve madde analizleri yapılmıştır. Çalışmanın araştırma grubunu, 20172018 eğitim öğretim yılı içerisinde lise öğrenimine devam eden toplam 549 öğrenci oluşturmaktadır. Ölçeğin görünüş ve kapsam geçerliği için uzman görüşünden yararlanılmıştır. Yapı geçerliği kanıtlarını elde etmek için ise farklı örneklemler üzerinde açımlayıcı ve doğrulayıcı faktör analizi yapılmıştır. Açımlayıcı faktör analizi sonucunda altı faktörlü bir yapı elde edilmiştir. Aynı faktör altında toplanan maddelerin içerikleri ve alan yazın dikkate alınarak faktörler sırasıyla "Mekân Yeterliği”, "Kişisel Gelişim", "Toplumsal Değer Bilinci", "Mekân Çekiciliği”, "Teknolojik Destek" ve "Spor ve Sanat Desteği" olarak adlandırılmıştır. Faktörlerin toplam varyansın \%66.11'ini açıkladığı belirlenmiştir. Doğrulayıc1 faktör analizi sonucunda ise altı faktörlü yapının veriye iyi uyum sağladığı görülmüştür. Güvenirlik kanıtlarını elde etmek için Cronbach Alfa $(\alpha)$, tabakalanmış alfa ve bileşik (composite) güvenirlik katsayıları hesaplanmıştır. Hesaplamalar sonucunda ölçek maddelerinin ölçülmek istenen özelliği güvenilir şekilde ölçtükleri belirlenmiştir. Madde analizi sonucunda ölçekte bulunan tüm maddelerin ölçülen özelliği ölçmede ayırt edici oldukları görülmüştür. Tüm bu bulgular ışı̆̆ında öğrenci algılarına dayalı olarak okul etkililiğinin belirlenmesinde Algılanan Etkili Okul Ölçeği'nin geçerli ve güvenilir ölçümler üreten bir ölçek olarak kullanılabileceği söylenebilir.

Anahtar sözcükler: etkili okul, ölçek geliştirme, güvenirlik, geçerlik

Atıf:

Lafcı-Tor, D., ve Yavuz, E. (2020). Algılanan okul etkililiği ölçeği'nin geliştirilmesi: Geçerlik ve güvenirlik çalışması. Pamukkale Üniversitesi Eğitim Fakültesi Dergisi, 49, 506-529. doi: 10.9779/pauefd.595719

\footnotetext{
1 Bu çalışma 3.Uluslararası Sosyal Bilimleri Kongresinde “(USBIK 2020), Kayseri, Türkiye, 29 - 31 Ocak 2020" sözlü bildiri olarak sunulmuştur

2 Arş. Gör. Dr., Kayseri Erciyes Üni. Eğitim F. Eğitim Bil. Böl.durdaneltor@gmail.com, https://orcid.org/0000-0003-2373-1247

2 Arş. Gör., Kayseri Erciyes Üni. Eğitim F. Eğitim Bil. Böl. yavuzemine0@gmail.com, https://orcid.org/0000-00021991-1416
} 


\begin{abstract}
The purpose of this study is to develop a scale that provides valid and reliable measurements in determining school effectiveness based on student perceptions. The study group consisted of 549 high school students in 2017-2018 academic year. Expert opinion was taken into consideration for the face and content validity of the scale. For the construct validity, exploratory (EFA) and confirmatory (CFA) factor analyses were conducted on different samples. As a result of EFA, a six-factor structure was obtained. Factors were named as "Space Adequacy", "Personal Development", "Social Value Consciousness", "Place Attractiveness", "Technological Support" and "Sports and Art Support". The factors explained $66.11 \%$ of the total variance. As a result of CFA, it was found that the six-factor structure had good fit of the model. In order to obtain evidence for its reliability, coefficients of Cronbach's alpha $(\alpha)$, stratified alpha and composite reliability were calculated. Results indicated that the scale items could measure the construct reliably. Item analysis proved that all the items had high discrimination in measuring the measured construct. As a result, it can be concluded that Perceived Effective School Scale is a scale that provide valid and reliable measurements in determining school effectiveness based on student perceptions.
\end{abstract}

Keywords: effective school, scale development, validity, reliability

\title{
Cited:
}

Lafc1-Tor, D., ve Yavuz, E. (2020). Development of perceived school effectiveness scale: Validity and reliability study. Pamukkale Üniversitesi Eğitim Fakültesi Dergisi, 49, 506-529. doi: 10.9779/pauefd.595719 


\section{Giriş}

Bir sosyal kurum olarak eğitimin (Şişman, 2014) sürdürüldüğü yerlerden okullar, kabul görmüş toplumsal değerlerin yeni nesillere kazandırılması için büyük sorumluluklar taşımaktadır. Çağlar boyunca insanın eğitimi için farklı felsefeler, farklı tezler ileri sürülmüş, eğitim sistemleri ve modelleri geliştirilmiş olsa da, eğitimin gerçekleştiği yerler hep "okul” olmuştur. Eğitim sisteminin en stratejik birimi olan okulların yapısı, okul içinde yer alan çeşitli roller, statüler, görevler, yetkiler ve sorumluluklardan meydana gelir (Şişman, 2014). Tüm bu öğelerin belli bir sistem içinde düzenlenmesindeki amaç, okulun ve eğitimin amaçlarını gerçekleştirmek; dolayısıyla daha etkili bir eğitim ve öğretime ulaşmaktır. Okullarda düzenlenen planlı eğitimsel etkinlikler önceden düzenlenmiş belirli amaçlara dönüktür. Bu amaçlar Türk Eğitim Sistemi'nde üç ana başlık altında yer almaktadır (Milli Eğitim Temel Kanunu, 1973). Milli Eğitim Temel Kanunu'nda ilk amaç demokratik, laik ve sosyal yurttaşlar yetiştirmeyi, ikinci amaç yapıcı, yaratıcı ve verimli bireyler yetiştirmeyi, son amaç ise ilgi ve kabiliyetleri doğrultusunda bireylere meslek edindirmeyi işaret etmektedir. Bu doğrultuda, okulun görevleri sosyal-kültürel, politik, ekonomik ve bireysel olarak gruplanabilir (Bursalığlu, 2002; Şişman ve Turan,2004).

Okuldaki eğitimin ve öğretimin genel amacı istenen bilgi, beceri ve davranış yönünde çocukların sağlıklı ve nitelikli bireyler olarak yetişmelerini sağlamaktır. Bir okulun bu amaçlara ulaşıp ulaşmadığını araştıran çalışmalara genel adıyla "etkili okul" çalışmaları denmektedir. Coleman (1966)'ın ve Jencks (1971)'in “okullar fark yaratmaz" varsayımını ortaya attıkları araştırmaları "etkili okul çalışmalarını" gündeme getirmiştir. Coleman (1966) ve Jencks (1971) çalışmalarında öğrencilerin akademik başarılarındaki farklılıklara sebep olan etkinin, okuldan çok öğrencilerin ailelerinden kaynaklandığını belirtmişlerdir. Bu bulguya karşı çıkan birçok araştırmac1 (örn. Brookover, Beady, Flood, Schweitzer, Wisenbaker, 1979; Brookover \& Lezotte, 1979; Edmonds \& Frederikson, 1978; Weber, 1971) sosyo ekonomik durumu düşük olan öğrencilerin nasıl başarıya ulaştıklarını inceleyen araştırmalar yürütmüşlerdir. Bunlardan Edmonds (1981), etkili okul bileşenlerini şu şekilde belirlemiştir: 1) Öğretimsel liderliğin güçlü olması, 2) temel becerilerin kazandırılmasına odaklanılması, 3) öğrenci başarısına ilişkin yüksek beklentilerin olması, 4) öğrenmeyi kolaylaştıracak güvenli ve düzenli bir çevrenin oluşturulması ve 5) öğrenci gelişiminin sürekli kontrol edilmesi. Bu beş bileşene Lezotte (1991) "öğrenme fırsatları ve zamanın etkili kullanımı" ve "okul-aile ilişkileri" bileşenlerini ekleyerek etkili okulu 7 bileşenle tanımlamıştır. Sackney (1986) ise bu bileşenlere ek olarak öğrenme iklimine odaklanmıştır. Sackney (1986), öğrenme iklimini öğrencilerin okul etkinliklerine gönüllü ve aktif olarak katıldıkları, koşulsuz kabul gördükleri, rahat ve mutlu oldukları ortamı olarak ifade etmiştir.

Okul etkililiği çalışmalarının merkezi "okulların önemli olduğu, okulların çocukların gelişimi üzerinde büyük etkileri olduğu ve okulların bir fark yarattığı" fikrine ilişkindir (Reynolds ve Creemers, 1990, s.l). Yürütülen çalışmalar etkili okula ait farklı tanımlar ortaya çıkarmıştır. Bir tanıma göre etkili okul, öğrencilerin bilişsel, duyuşsal, devinimsel, estetik ve sosyal gereksinimlerini karşılayacak uygun öğrenme ortamı sağlayan okuldur (Brookover, 1985; Klopf ve diğerleri, 1982). Barnard (1948) ve Lezotte (1993) ise bir okul amaçlarına ulaşıyor ise onun etkili okul olduğunu ifade etmektedirler. Tüm bu tanımlardan yola çıkarak okul etkililiği, okulların öğrenci bilgi, beceri ve davranışlarında meydana getirdiği gelişime bağlıdır (Purkey ve 
Smith,1985, s.353). Mortimore (1991), eğer bir okulun öğrencilerinin başlangıç durumları göz önüne alındığında öğrenciler beklenenden daha fazla ilerlemişse o okulu etkili bir okul olarak tanımlamaktadır. Etkili bir okul, benzer hizmet veren diğer okullara kıyasla, öğrencilerin sonuçlarına katma değer katandır (Mortimore, 1991).

Türkiye'de okul etkililiği çalışan araştırmacılardan Balcı (2002) ise, çocukları bilişsel, duyuşsal, devinişsel ve sosyal yönden geliştirdikleri; özetle amaçlarına ulaştığı takdirde okulların etkili olduğundan bahseder. Bu özelliklerin yanı sıra Taş (2007), etkili okul için okulların demokratik bir yaklaşımla yönetilmesini ve bu yolla demokratik bireyler yetiştirilmesini önemli görmektedir. Türkiye'de yapılan çalışmalarda genel olarak "okul yöneticisi", "öğretmenler", "öğrenciler" ve "veliler" etkili okulun bileşenleri olarak kabul edilmektedir (Balc1, 2002; Baştepe, 2002; Şişman, 1996). Bu bileşenlere ek olarak okul ortam1 (Balc1, 2002), okul kültürü (Şişman, 1996), okul iklimi (Baştepe, 2002), okul programı ve eğitim-öğretim süreci (Baştepe, 2002; Şişman, 1996) ve fiziksel ortam (Baştepe, 2002) da dikkate alınmaktadır.

Türkiye'de okul etkililiği üzerine yapılan çalışmaların büyük bir çoğunluğu yönetici ve öğretmen görüşlerine dayanmaktadır (Aksu, 1994; Demirtaş, 1997; Keles, 2006; Köksal, 1991; Oral, 2005; Şişman, 1996; Tınmaz, 2000; Yelok, 2006; Yenipınar, 1998; Yılmaz, 2006; Yörük ve Şahin, 2012). Araştırma sonuçları genel olarak en etkili boyutun yönetici boyutu olduğu ve en az etkili boyutun ise; okul çevresi ve veli boyutu olduğunu göstermiştir (Akan, 2007; Kaplan, 2008; Keleş, 2006; Şişman, 1996; Tunçel, 2008; Yılmaz, 2006). Bazı çalışmalarda ise tüm okul etkililiği bileşenlerinden ziyade sadece okul yöneticilerinin etkililiğine bakılmıştır (Cerit ve Yıldırım, 2017; Çınar, 2010; Koçak ve Helvacı, 2011). Ayrıca, bazı çalışmaların okulların etkililiğini engelleyen sorunları tespit etmek amaçlı gerçekleştirildiği söylenebilir (Balcı, 2001; Çelikten, 2001; Keleş, 2006; Şişman, 2002).

Tüm alan yazın incelendiğinde, okulların etkili olabilmesi için sahip olması gereken özellikler şu şekilde özetlenmiştir (Özdemir, 2000; Özdemir ve Sezgin, 2002):

1. Okul açık amaçlar üzerine oturtulmuş misyona sahip olmalıdır.

2. Öğretim liderliğine sahip çıkan yöneticiler tarafından etkin bir şekilde yönetilen bir sisteme sahip olmalidir.

3. Öğrencilerden gelişimi için yüksek beklentiler oluşturulmalıdır ve bu doğrultuda öğrencilere firsatlar sunulmalıdır.

4. Temel becerilerin kazandırılmasına önem verilmelidir.

5. Öğrenci gelişimi düzenli ve sistematik bir biçimde kontrol edilmelidir.

6. Okul-aile işbirliğine önem verilmelidir.

7. Uygun okul iklimi oluşturulmalıdır.

Türkiye'de yapılan çalışmalarda okul etkililiğinin belirlenmesinde altı farklı ölçeğin kullanıldığ1 görülmektedir: 1) Hoy-Ferguson (1985), Algılanan Okul Etkililiği Ölçeği, 2) Scheerens (1992), Etkili Okul Ölçeği, 3) Hoy ve Sweetland (2000), Okul Yapısının Etkililiği Ölçeği Okul Yapısının Etkililiği Ölçeği 4) Balcı (2001), Etkili Okul Ölçeği. 5) KasapÇobanoğlu (2008), Okul Etkililiği Ölçeği ve 6) Günal (2014) Okul Etkililiği Ölçeği. 
Türkiye'de kullanılan bu ölçeklerden ilki Hoy ve Ferguson'a ait 8 maddelik tek boyuttan oluşan ölçektir. Bir okulun öğretmenleri tarafından algılanan etkililiğini ölçen bu ölçek, ülkemizde en çok kullanılan ölçektir (Alanoğlu, 2014; Cerit ve Yıldırım, 2017; Negiş-Işık ve Gümüş, Şenel ve Buluç, 2016; 2017; Yıldırım, 2015; Yıldırım, Akan ve Yalçın, 2017). Scheereens (1992) tarafından geliştirilip Heneceld (1994) tarafindan gözden geçirilen ikinci ölçek 5 boyuta sahiptir. Okul girdileri (14 madde), okul iklimi (26 madde), sağlanan koşullar (14 madde), öğrenme-öğretme süreci (10 madde) ve öğrenme-öğretme süreci sonuçları (6 madde) bu ölçeğin boyutlarını oluşturmaktadır. Arslan (2004) tarafından Türkçe'ye uyarlanan bu ölçek öğretmenlere uygulanmaktadır. Üçüncü ölçek olan Hoy ve Sweetland tarafından geliştirilen ölçek tek boyuttan 12 maddeden oluşmaktadır ve diğer ölçekler gibi öğretmenlere uygulanmaktadır. Diğer ölçek, Balcı (2001) tarafından geliştirilmiştir. Ölçek 5 alt boyuttan oluşmaktadır: Okul yöneticisi (12 madde), öğretmenler (23 madde), okul ortamı (20 madde), öğrenciler (6 madde) ve veliler (6 madde). Bu ölçek de öğretmenlere uygulanmaktadır. Diğer ölçek, Kasap-Çobanoğlu (2008) tarafindan doktora tezi kapsamında geliştirilmiştir ve 61 maddeden oluşmaktadır. Ölçeğin alt boyutlarını Güvenli ve Düzenli Çevre (7 madde), Açık Okul Misyonu ve Amaçları (7 madde), Yüksek Beklentiler (6 madde), Okul Zamanının Etkili Kullanımıyla Öğrenme Fırsatları Sağlama ve Öğrenci Gelişiminin Gözlenmesi (17 madde), Öğretimsel Liderlik (14 madde) ve Aile-Okul İlişkileri (10 madde) oluşturmaktadır. Bu ölçek ayrıca Kaymaz ve Uyar (2016) tarafından gerçekleştirilen bir çalışmada da kullanılmıştır. Son ölçek ise, Günal (2014) tarafından geliştirilmiştir. Veli Okul İlişkisi (7 madde), Öğretimsel Liderlik (7 madde), Düzenli ve Güvenli Çevre (4 madde), Yüksek Başarı Beklentisi (3 madde), Öğrenci Öğrenmelerinin İzlenmesi ve Öğrenme Fırsatı (3 madde) alt boyutlarından oluşan bu ölçeğin öğrenciler ve öğretmenler için iki ayrı formatı vardır. Ulaşılabilen ölçekler arasında bu ölçek Türkiye'de ortaokul öğrencilere uygulanan tek ölçektir.

Okul etkililiği kavramı araştırılması gereken birçok bileşen barındırmaktadır. Tüm bileşenleri içeren bir ölçeğin uygulanabilirliği zordur. Bu nedenle okul etkililiği ölçekleri, farklı etkili okul bileşenleri içerir. Bu çalışmada ise etkili okulun birçok araştırmacı tarafından kabul edilmiş değişkenleri üzerine odaklanılmıştır: Okulun açık misyonu/amacı olması, öğrenci başarısına ilişkin yüksek beklentilerin olması, öğrenmeyi kolaylaştıracak güvenli ve düzenli bir çevrenin oluşturulması ve okul iklimi. Ayrıca etkili okul ölçeklerine bakıldığında daha çok öğretmenlere uygulanabilecek ölçeklerin kullanıldığı açıktır. Oysaki etkili okulun bir bileşeni olarak öğrenciler ve onların görüşlerini almak da etkili okulun tespit edilmesi için önemlidir. Bu nedenle öğrencilere uygulanacak ölçeklerin geliştirilmesi gereklidir. Öte yandan, ulaşılabilen ölçekler arasında öğrencilerin fikirlerini almaya yönelik olan tek ölçek olan Günal'ın (2014) ölçeğinden farklı olarak, bu çalışmada geliştirilen ölçekte etkili okulun farklı bileşenlerine odaklanılmaktadır. Bu farklılık öğrencilerin okulun amaçlarına yönelik görüşlerini temel almaktadır. Ayrıca, Günal'ın çalışmasında fiziksel çevreye yönelik bileşen, mevcut ölçekte okulun amaçlarını gerçekleştirebilme durumunu gösterir nitelikte oluşturulmuştur. Bunun dışında, alan yazın incelendiğinde Türkiye'de geliştirilmiş ölçekler olmasına rağmen daha çok yabancı araştırmacılar tarafından geliştirilen ve uyarlaması yapılan ölçeklerin tercih edildiği görülmektedir. Bunun nedeni olarak Türkiye'de geliştirilen ölçeklerin madde sayısının fazla olmasının ölçeklerin kullanışl1lığını düşürdüğü düşünülmektedir. Bu nedenle Türk Eğitim Sistemi ve okullarına özgü özelliklerin dikkate alınacağı kullanışlı ölçekler geliştirilmelidir. 


\section{Araştırmanın Amacı}

$\mathrm{Bu}$ çalışmanın amacı, öğrenci algılarına göre okul etkililiğinin belirlenmesinde geçerli ve güvenilir ölçümler sağlayacak bir ölçek geliştirilmesidir.

\section{Yöntem}

\section{Çalışma Grubu}

Çalışmanın araştırma grubunu amaçlı örnekleme yöntemi kullanılarak ulaşılan Kayseri ilinde bulunan üç devlet lisesi oluşturmaktadır. Bu liselerden iki tanesi Anadolu Lisesi bir tanesi ise Mesleki ve Teknik Anadolu Lisesidir. Ölçeğin ölçtüğü yapının belirlenmesi için iki Anadolu lisesinden elde edilen veri üzerinde açımlayıcı faktör analizi (AFA) yapılmıştır. Ölçeğin farklı bir örneklem üzerinde aynı yapıyı ölçüp ölçmediğinin belirlenmesi için Mesleki ve Teknik Anadolu Lisesinden elde edilen veriler kullanılarak doğrulayıcı faktör analizi (DFA) yapılmıştır. Alan yazında AFA ve DFA'nın farklı örneklemlere uygulanmasının daha doğru bir yaklaşım (Fabrigar, Wegener, MacCallum ve Strahan, 1999) olduğunun belirtilmesi çalışmanın bu şekilde yürütülmesinde etkili olmuştur. Çalışmanın araştırma grubunu, 2017-2018 eğitim öğretim yılı içerisinde lise öğrenimine devam eden toplam 549 öğrenci oluşturmaktadır. Çalışma grubunu oluşturan liselerde öğrenimlerine devam eden öğrencilere ait yüzde ve frekans dağılımları Tablo 1 'de verilmiştir.

Tablo 1. Araştırma Örneklemine Ait Yüzde ve Frekans Dağılımları

\begin{tabular}{llccccccc}
\hline & & Toplam & \multicolumn{2}{c}{ Cinsiyet } & \multicolumn{4}{c}{ Sinıf düzeyi } \\
& & $N$ & Kadın & Erkek & 9. sinıf & 10. sinıf & 11. sinıf & 12.sınıf \\
\hline \multirow{2}{*}{ Anadolu Liseleri } & $f$ & 347 & 183 & 164 & 115 & 82 & 73 & 77 \\
& $\%$ & & $\% 53$ & $\% 47$ & $\% 33$ & $\% 24$ & $\% 21$ & $\% 22$ \\
\multirow{2}{*}{$\begin{array}{l}\text { Mesleki ve Teknik } \\
\text { Anadolu Lisesi }\end{array}$} & $f$ & 297 & 3 & 294 & 87 & 98 & 82 & 30 \\
& $\%$ & & $\% 1$ & $\% 99$ & $\% 29$ & $\% 33$ & $\% 28$ & $\% 10$ \\
\hline Toplam & $f$ & 644 & 186 & 458 & 202 & 180 & 155 & 107 \\
& $\%$ & & $\% 29$ & $\% 71$ & $\% 31$ & $\% 28$ & $\% 24$ & $\% 17$ \\
\hline
\end{tabular}

Araştırmanın veri toplama aşamasında farklı cinsiyetlerden ve sınıf düzeylerinden birbirine yakın sayıda öğrenciye ulaşılması amaçlanmıştır. Fakat Mesleki ve Teknik Anadolu Liselerin mevcudunun çoğunluğunu erkek öğrencilerin oluşturması (Eğitim Reformu Girişimi [ERG], 2015, s.11-38) nedeniyle bu okulda az sayıda kız öğrenciye ulaşılabilmiştir. Ayrıca Mesleki ve Teknik Anadolu Liselerindeki öğretim programında 11. ve 12. sınıflarda staj etkinliğine yer verilmesi (ERG, 2015, s.17) nedeniyle 12. sinıf düzeyinde öğrenimine devam eden az sayıda öğrenciye ulaşılabilmiştir. Sonuç olarak, Anadolu lisesinde öğrenim gören 183'ü (\%53) kadın, 164'ü (\%47) erkek toplam 347 öğrenciye; Mesleki ve Teknik Anadolu Lisesinde ise 3'ü kadın (\%1), 294’ü erkek (\%99) toplam 297 öğrenciye ulaşılmıştır.

\section{Ölçeğin Geliştirilme Süreci}

Ölçek maddelerine ait havuz hazırlanmadan önce alan yazın taraması yapılmış etkili okul özellikleri neler olabileceğine dair bilgilere ulaşılmaya çalışılmıştır. Ayrıca alan yazında benzer konuda yapılmış gerek uluslararası geniş ölçekli uygulamalar gerekse bireysel çalışmalarda hazırlanmış ölçekler ve maddeleri incelenmiştir. Etkili okulun birçok araştırmacı tarafindan 
kabul edilmiş değişkenleri üzerine odaklanılmıştır: Okulun açık misyonu/amacı olması, öğrenci başarısına ilişkin yüksek beklentilerin olması, öğrenmeyi kolaylaştıracak güvenli ve düzenli bir çevrenin oluşturulması ve okul iklimi. Alan yazın taraması sonucunda edinilen bilgiler ışı̆̆ında ölçeğe ait 53 maddeden oluşan madde havuzu hazırlanmıştır. Madde havuzunun, okul etkililiğini ortaya koymak için ele alınan boyutları tüm yönleriyle temsil etmesine, başka bir deyişle madde havuzunun kapsam geçerliğinin yüksek olmasına dikkat edilmiştir. Yazılan maddelerin ele alınan boyutları temsil etme düzeylerinin uzmanlar tarafından kontrol edilmesi gerekmektedir (DeVellis, 2003). Bu nedenle madde havuzunun kapsam ve görünüş geçerliğinin kontrolü eğitim bilimlerinde çalışmalarını sürdüren bir uzmandan görüş alınarak gerçekleştirilmiştir. Uzmandan gelen dönütlerin değerlendirilmesiyle iki maddenin ölçekten çıkartılmasına karar verilmiştir. Bu maddeler ile benzer özellikleri ölçen başka maddeler olduğu için ölçeğin kapsam geçerliği korunmuştur. Ayrıca uzman görüşlerinin değerlendirilmesiyle bazı maddeler yeniden düzenlenmiştir. Ölçeğin dilsel anlaşılırlık kontrolü için ise Türkçe eğitiminde çalışmalarını sürdürmekte olan bir uzmandan görüş alınmıştır. Uzmanın görüşleri doğrultusunda gerekli noktalama ve yazım yanlışları düzeltilerek ölçeğin 51 maddelik deneme formu oluşturulmuştur.

Ölçeğin cevaplanmasında "Kesinlikle Katılmıyorum (1)", "Katılmıyorum (2)", "Kararsızım (3)", "Katıllyorum (4)" ve "Kesinlikle Katıllyorum (5)" şeklinde beşli Likert tipinde derecelendirme kullanılmıştır. Ölçeğin deneme formunda M2, M4, M5, M6, M8, M10, M23, M28, M30, M38, M39 maddeleri olumsuz ifade içermektedir. Bu nedenle yap1 geçerliği kontrolü için yapılan analizlerde ters kodlanmışlardır. Ölçeğin nihai formunda ise ters kodlanması gereken madde kalmamıştır. Ölçekten alınan yüksek puan, öğrencilerin algılarına göre öğrenimlerine devam ettikleri okulun etkisinin yüksek olduğunu gösterir.

\section{Verilerin Analizi}

Analizlere başlamadan önce elde edilen verilerin düzenlenmesi (olumsuz maddelerin ters kodlanması ve kayıp verilerin temizlenmesi) gerekmektedir. Verilerin SPSS programına yanlış girilmesiyle oluşabilecek hatalar kontrol edildikten sonra birkaç maddeyi boş bırakan veya aynı maddede birden fazla işaretleme yapan öğrencilere ait veriler ayıklanmıştır. Sonuç olarak öğrenimine Anadolu lisesinde devam eden 315 öğrenciye, Mesleki ve Teknik Anadolu Lisesinde ise 234 öğrenciye ait veri kalmıştır. Ölçeğin geçerlik ve güvenirlik kanıtları bu veriler üzerinden elde edilmiştir. Veriler düzenlendikten sonra yapı geçerliği kanıtlarını elde etmek için sırasıyla AFA ve DFA yapılmıştır.

Anadolu Lisesi $(\mathrm{N}=315)$ verisinin AFA'ya uygunluğunun belirlenmesi için öncelikle bazı sayıltıların karşılanması gerekmektedir. $\mathrm{Bu}$ sayıltılar, kayıp değerler, örneklem büyüklüğünün uygunluğu, normallik, uç değerler, doğrusallık ve çoklu bağlantı sorunudur. Veri düzenlemesi aşamasında eksik işaretleme yapan öğrencilerin verisi çıkarıldığı için kayıp veri bulunmamaktadır. Alan yazında faktör analizi için yeterli örneklem büyüklüğü hakkında çeşitli görüşler mevcuttur. Bu görüşlerden bir tanesi, faktör analizinin yapılabilmesi için örneklem büyüklüğünün madde sayısının en az iki katı kadar olmasıdır (Çokluk, Şekercioğlu ve Büyüköztürk, 2012, s.206). Bir başka görüş ise örneklem büyüklüğü ne kadar fazla ise o kadar iyi olacağı görüşüyle birlikte net bir faktör yapısının 100 kişilik bir örneklemde genellikle güvenilir sonuçlar elde edilerek analiz edilebileceğidir (Kline, 1994, s.73). Crocker ve Algina (1986, s.296), ise faktör analizi için örneklem büyüklüğünün madde sayısının en az 10 katı 
olmas1 gerektiğini belirtmişlerdir. Çokluk, Şekercioğlu ve Büyüköztürk (2012, s.207) AFA için gerekli örneklem büyüklüğ̈̈nün seçiminde alan yazında bulunan ölçütlerden en az ikisinin sağlanmasını önermişlerdir. Mevcut çalışmada ölçek 51 maddeden oluşmaktadır. Çalışmada örneklem büyüklüğü $(\mathrm{N}=315)$, madde sayısının yaklaşık altı katı ve 200 öğrenciden fazla olduğundan verinin AFA için uygun olduğu söylenebilir. Ayrıca örneklem büyüklüğünün AFA için yeterli olup olmadığının belirlenmesi için KMO değeri incelenmiştir. KMO değerinin 0.60 'den daha büyük olması verinin faktör analizi için uygun olduğu anlamına gelmektedir (Tabachnick ve Fidel, 2012, ss.619-620). Mevcut çalışmanın KMO değeri 0.91 olduğu için veri örneklem büyüklüğü açısından AFA analizine uygundur. Çalışmada daha sonra verilerin tek ve çok değişkenli normal dağılımları incelenmiştir. Tek değişkenli dağılım için maddelerin çarpıklık ve basıklık katsayı incelenmiş ve normal dağıldıkları belirlenmiştir. Çok değişkenli normal dağılımın belirlenmesi için Bartlett's Küresellik Testi sonuçları incelenmiştir. Bartlett's test sonuçlarının istatistiksel olarak anlamlı $(B=5766.673,990, \mathrm{p}<0.001)$ olduğundan verinin faktör analizi için uygun olduğu söylenebilir (Tabachnick ve Fidel, 2012, s.619). Ayrıca çalışmada sırasıyla uç değerler, doğrusallık ve çoklu bağlantı (değişkenler arası r=0.00-0.64 arasında değişmektedir) sayıltıları da kontrol edilmiş, sayıltıların sağlandığı belirlendikten sonra AFA'ya geçilmiştir.

Alan yazında çeşitli faktörleşme teknikleri mevcuttur. Bunlardan bazıları temel bileşenler analizi, temel faktör analizi, maksimum olasılık faktör analizi, alfa faktörleşme analizi, imaj faktör analizi, ağırlıklandırılmamış en küçük kareler analizi ve ağırlıklandırılmış en küçük kareler analizidir (Çokluk, Şekercioğlu ve Büyüköztürk, 2012, ss.198-200). Çalışmada kullanım kolaylığı ve veri setinden her bir bileşenle en fazla varyansı çıkarmak için temel bileşenler faktörleşme tekniği kullanılmıştır. Ölçek geliştirme sürecinde faktör analizi ile ölçülen yapı hakkında daha çok bilgi edinmek veya elde edilen sonuçların daha anlaşılır yorumunun yapılması için döndürme yapılır (Çokluk, Şekercioğlu ve Büyüköztürk, 2012, s.200). Alan yazında dik ve eğik döndürme başlıkları altında toplanan çeşitli döndürme teknikleri vardır (Çokluk, Şekercioğlu ve Büyüköztürk, 2012, s.200-2005). Bu çalışmada faktörlerin birbirleriyle ilişkisiz oldukları düşünüldüğü için dik döndürme yöntemlerinden olan varimax döndürme yapılmıştır.

AFA sonucu maddeler hakkında değerlendirme, onların faktör yüklerine ve açıkladıkları ortak faktör varyansı $\left(h^{2}\right)$ ölçütüne göre yapılmıştır. Madde faktör yük değerlerinin değerlendirilmesinde alan yazında çeşitli ölçütler bulunmaktadır. Örneğin Tabachnick ve Fidell (2012, s.654), faktör yük değerlerinin .32 ve üzeri olması gerektiğini Crocker ve Algina (1986, s.299) ise .30 ve üzerinin yeterli olduğunu belirtmişlerdir. Bu çalışmada binişik veya faktör yük değeri .30'un altında olan maddeler analizden çıkarılmıştır. Ortak faktör varyansının değerlendirilmesine ilişkin fen ve sosyal bilimlerde farklı ölçütler mevcuttur. Sosyal bilimlerde yüksek ortak faktör varyansına her zaman ulaşmak zordur (Costello ve Osborne, 2005). Bu nedenle Costello ve Osborne (2005) ölçüt olarak .40 alınabileceğini, Tabachnick ve Fidell (2012; ss.664-667) ise .20 varyansından düşük çok fazla madde varsa bunun maddeler arası heterojenliğin işareti olabileceğini belirtmişlerdir. Çalışmada ortak faktör varyansına ilişkin ölçüt olarak ise .20 alınmıştır.

Ölçeğin farklı bir örneklemde aynı yapıyı ölçüp ölçmediğinin test edilmesi için Mesleki ve Teknik Anadolu Lisesi verisi üzerinde DFA yapılmıştır. Alan yazında DFA analizi 
sonucunda model veri uyumunun değerlendirilmesinde kullanılan çeşitli indeksler ve bu indekslere ait çeşitli ölçütler vardır. Bu indekslerden hangilerinin hangi ölçütlerle kullanılacağ1 net olmadığı (Wetson ve Gore, 2006) için bu çalışmada çeşitli indekslere ve bu indekslerin ölçütlerine yer verilmiştir. Bu indeksler Ki-Kare $\left(\chi^{2}\right)$ iyilik uyum testi (Chi-square goodness of fit), yaklaşık hataların ortalama karekökü (Root Mean Square Error of Approximation, RMSEA), standardize edilmiş artık ortalamaların karekökü (Standardized Root Mean Square Residual, SRMR), iyilik uyum indeksi (Goodness of Fit Index, GFI), s1k1 iyilik uyum indeksi (Parsimony Goodness of Fit Index, PGFI), karşılaştırmalı uyum indeksi (Comparative Fit Index, CFI), normlaştırılmamış uyum indeksi (Non-Normed Fit Index, NNFI), normlaştırılmış uyum indeksi (Normed Fit Index, NFI), sıkı normlaştırılmış uyum indeksi (Parsimony Normed Fit Index, PNFI) ve artımlı uyum indeksidir (Incremental Fit Index, IFI).

Ki-Kare $\left(\chi^{2}\right)$ iyilik uyum (Chi-Square Goodness) testinde modelin veriye yeterince uyum sağlayıp sağlamadığı test edilir ve $p$ değerinin .05 'ten büyük çıkması istenir. Fakat bu test büyük örneklemden etkilendiği için $p$ değerinin .05'ten küçük çıkması olasıdır (Kline, 2016, s.271). Bu nedenle DFA'da standardize edilmiş $\chi^{2}$ değeri incelenir (Hu ve Bentler, 1999). $\chi^{2} / \mathrm{sd}$ değerinin 0 ile 2 arasında yer alması mükemmel uyumu, 2 ile 3 arasında yer alması ise kabul edilebilir uyumu göstermektedir (Marsh, Hau, Artelt, Baumert ve Peschar, 2006; SchermellehEngel, Moosbrugger ve Müller, 2003). RMSEA indeksinin 0 ile .05 arasinda yer almas1 mükemmel uyumu, .05 ile .08 arasında yer alması ise kabul edilebilir uyumu göstermektedir (Sümer, 2000). SRMR indeksinin 0 ile .05 arasında yer alması mükemmel uyumu, .05 ile .10 arasında yer alması ise kabul edilebilir uyumu göstermektedir (Hu ve Bentler, 1999). GFI, CFI, NNFI, NFI ve IFI indeksleri için benzer ölçütler geçerlidir. Bu indekslerin .95 ile 1.00 arasında yer alması mükemmel uyumu, .90 ile .95 arasinda yer alması ise kabul edilebilir uyumu göstermektedir (Bentler ve Bonett, 1980; Hu ve Bentler, 1999; Marsh, Hau, Artelt, Baumert ve Peschar, 2006; Tabachnick ve Fidell, 2012; ss.721-724). PGFI ve PNFI indekslerinde de benzer ölçütler geçerlidir. Bu indekslerin .50 ile .95 arasında yer alması kabul edilebilir uyumu göstermektedir (Meyers, Gamst ve Guarino, 2006). Uyum indeksleri ölçütlerine göre değerlendirildikten sonra maddelerin $t$ değerleri kontrol edilmiştir. 2.58'den büyük $t$ değerine sahip olan maddeler .01 düzeyinde, 1.96 'dan büyük olanlar .05 düzeyinde anlamlı olarak değerlendirilir. Anlamlı bulunmayan $t$ değerine sahip maddelerin analizden çıkarılması ve analizin tekrar edilmesi gerekmektedir (Kline, 2016, s.51).

Ölçeğin alt boyutlarının güvenirliğini hesaplamak için Cronbach Alfa $(\alpha)$, geneline ait güvenirlik katsayısı elde etmek için tabakalanmış alfa katsayısı hesaplanmıştır. Birden fazla boyuttan oluşan bir ölçekte toplam test puanlarının güvenirliğini kestirmek için tabakalanmış alfa (stratified alpha) kullanılması önerilmektedir (Tan, 2014, s.154). Ayrıca ölçek geneline ve alt boyutlarına ait bileşik güvenirlik katsayısı hesaplanmıştır. Alfa ve bileşik güvenirlik katsayı arasındaki fark, alfanın AFA sonucu elde edilen bulgulardan, bileşik güvenirlik katsayısı ise DFA sonucu elde edilen bulgulardan yararlanılarak hesaplanmasıdır. Alan yazında .70 ve üzeri katsayıya sahip ölçümler güvenilir olarak kabul edilmektedirler (Tezbaşaran, 1997).

Madde ayırt ediciliği madde geçerliği için bir kanıt oluşturur (Erkuş, 2012, s.141). Bu nedenle çalışmada madde analizlerine yer verilmiştir. Ölçeğe ait madde analizleri her iki lise türüne ait veriler $(\mathrm{N}=549)$ birleştirilerek hesaplanmıştır. Çalışmanın madde analizleri kapsamında \%27'lik dilimlerde yer alan alt ve üst grup karşılaştırması ve düzeltilmiş madde 
toplam korelasyonu hesaplanmıştır. Düzeltilmiş madde toplam korelasyon değeri .40'tan düşük olan maddeler düşük korelasyona sahip maddeler (Erkuş, 2012, s.145) olarak değerlendirilmiştir. Alt-üst grup karşılaştırılması sonucu $t$ değeri anlamsız olan maddeler ayırt ediciliği düşük maddeler olduğu için analizden çıkarılmıştır.

Çalı̧̧mada AFA, Cronbach Alfa ve madde analizleri için SPSS 22 programı; DFA için Lisrell 8.80 programı ve tabakalanmış alfa ve bileşik güvenirlik katsayısı için Microsoft Excel 2010 programı kullanılmıştır.

\section{Bulgular}

\section{Yapı Geçerliği Kanıtları}

Ölçümlerin yapı geçerliği kanıtlarının elde edilmesi için AFA ve DFA yapılmıştır.

\section{Açımlayıcı faktör analizi (AFA)}

Şekil 1'de AFA'ya ait yamaç eğim grafiği verilmiştir. Grafik incelendiğinde yedinci düğümle birlikte çizginin eğiminin bitip yatay eksene yaklaşık olarak paralel devam ettiği görülmektedir. $\mathrm{Bu}$ durum ve alan yazınla birlikte ölçeğin altı faktörlü olarak daha kolay ve anlaşılır açıklanabileceği düşünülmektedir. $\mathrm{Bu}$ nedenle faktör sayısı altıya eşitlenerek analiz tekrarlanmıştır.

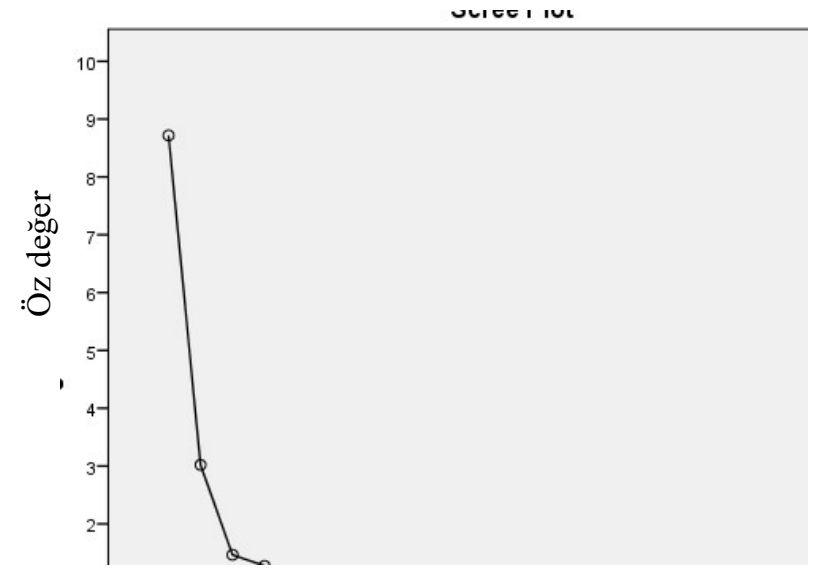

Bileşen sayıs1

\section{Şekil 1. AFA sonucu elde edilen yamaç eğim grafiği}

Döndürülmüş temel bileşenler analizi sonucunda binişik veya faktör yük değeri .30'un altında olan maddeler ve açıklanan ortak faktör varyansı .20'den düşük olan maddeler analizden çıkarılmıştır. Analiz sonucunda 25 maddenin ilgili oldukları faktördeki yükleri ve ortak faktör varyanslarına ait bulgular Tablo 2'de verilmiştir. Tablo 2 incelendiğinde maddelerin faktör yüklerinin .54 ile .82 arasında değiştiği görülmektedir. Maddelerin ortak faktör varyansları ise .29 ile .68 arasında değişmektedir.

Aynı faktör altında toplanan maddelerin içerikleri ve alan yazın dikkate alınarak faktörler sırasıyla "Mekân Yeterliği”, "Kişisel Gelişim”, “Toplumsal Değer Bilinci”, "Mekân Çekiciliği”, "Teknolojik Destek” ve "Spor ve Sanat Desteği” olarak adlandırılmışlardır. 
Tablo 2. Döndürme Sonucu Maddelerin Faktör Yük Değerleri ve Ortak Faktör Varyansları

\begin{tabular}{|c|c|c|c|c|c|c|c|}
\hline \multirow[b]{2}{*}{ Maddeler } & \multicolumn{6}{|c|}{ Faktörler } & \multirow{2}{*}{$\begin{array}{c}\text { Ortak } \\
\text { Faktör } \\
\text { Varyans1 } \\
h^{2}\end{array}$} \\
\hline & $\begin{array}{l}\text { Mekân } \\
\text { Yeterliği }\end{array}$ & $\begin{array}{l}\text { Kişisel } \\
\text { Gelişim }\end{array}$ & $\begin{array}{c}\text { Toplumsal } \\
\text { Değer } \\
\text { Bilinci }\end{array}$ & $\begin{array}{c}\text { Mekân } \\
\text { Çekiciliği }\end{array}$ & $\begin{array}{c}\text { Teknolojik } \\
\text { Destek }\end{array}$ & $\begin{array}{c}\text { Spor ve } \\
\text { Sanat } \\
\text { Desteği }\end{array}$ & \\
\hline $\mathrm{m} 40$ & 0.82 & & & & & & 0.68 \\
\hline $\mathrm{m} 41$ & 0.78 & & & & & & 0.61 \\
\hline $\mathrm{m} 42$ & 0.64 & & & & & & 0.41 \\
\hline $\mathrm{m} 45$ & 0.80 & & & & & & 0.64 \\
\hline $\mathrm{m} 48$ & 0.66 & & & & & & 0.43 \\
\hline $\mathrm{m} 16$ & & 0.62 & & & & & 0.39 \\
\hline $\mathrm{m} 17$ & & 0.82 & & & & & 0.67 \\
\hline $\mathrm{m} 18$ & & 0.80 & & & & & 0.64 \\
\hline $\mathrm{m} 22$ & & 0.55 & & & & & 0.30 \\
\hline $\mathrm{m} 31$ & & 0.63 & & & & & 0.39 \\
\hline $\mathrm{m} 33$ & & 0.54 & & & & & 0.29 \\
\hline $\mathrm{m} 12$ & & & 0.75 & & & & 0.56 \\
\hline $\mathrm{m} 13$ & & & 0.71 & & & & 0.51 \\
\hline $\mathrm{m} 15$ & & & 0.59 & & & & 0.35 \\
\hline m19 & & & 0.80 & & & & 0.64 \\
\hline $\mathrm{m} 20$ & & & 0.61 & & & & 0.37 \\
\hline m49 & & & & 0.64 & & & 0.41 \\
\hline $\mathrm{m} 50$ & & & & 0.79 & & & 0.62 \\
\hline m51 & & & & 0.79 & & & 0.63 \\
\hline $\mathrm{m} 25$ & & & & & 0.74 & & 0.54 \\
\hline $\mathrm{m} 32$ & & & & & 0.77 & & 0.59 \\
\hline $\mathrm{m} 37$ & & & & & 0.71 & & 0.51 \\
\hline $\mathrm{m} 34$ & & & & & & 0.69 & 0.48 \\
\hline $\mathrm{m} 35$ & & & & & & 0.73 & 0.53 \\
\hline $\mathrm{m} 36$ & & & & & & 0.71 & 0.51 \\
\hline
\end{tabular}

Döndürülmüş temel bileşenler analizi sonucunda faktörlerin açıkladıkları toplam varyans miktarları Tablo 3'te verilmiştir.

Tablo 3. Döndürme Sonucu Faktörlerin Öz Değer ve Açıklanan Varyans Miktarları

\begin{tabular}{lccc}
\hline Faktörler & Öz değer & Varyans \% & Kümülatif \% \\
\hline 1. Mekân Yeterliği & 3.41 & 13.63 & 13.63 \\
2. Kişisel Gelişim & 3.35 & 13.39 & 27.02 \\
3. Toplumsal Değer Bilinci & 3.29 & 13.14 & 40.16 \\
4. Mekân Çekiciliği & 2.24 & 8.96 & 49.12 \\
5. Teknolojik Destek & 2.20 & 8.81 & 57.93 \\
6. Spor ve Sanat Desteği & 2.05 & 8.18 & 66.11 \\
\hline
\end{tabular}

Tablo 3 incelendiğinde üç faktörden her birinin toplam varyansın yaklaşı \%13'ünü açıkladığı, diğer üç faktörün her birinin ise toplam varyansın yaklaşı \%8'ini açıkladığı görülmektedir. Ayrıca faktörlerin genel olarak toplam varyansın \%66.11'ini açıkladıkları belirlenmiştir.

\section{Doğrulayıcı faktör analizi}


DFA sonucunda ölçeğe ait uyum indeks değerleri, bu indekslerin kabul edilebilir ve mükemmel uyum ölçütleri Tablo 4'te verilmiştir. Ölçeğin uyum indeks değerleri $\chi_{(260)}^{2} / \mathrm{sd}=1.85$, $\mathrm{RMSEA}=.06, \mathrm{SRMR}=.06, \mathrm{GFI}=.83, \mathrm{PGFI}=.67, \mathrm{CFI}=.97, \mathrm{NNFI}=.97, \mathrm{NFI}=.94$, PNFI $=.81$ ve IFI=.97 olarak elde edilmiştir. Tablo 4 incelendiğinde bu indekslerden $\chi^{2} / \mathrm{sd}$, CFI, NNFI ve IFI'nın mükemmel uyum gösterdikleri, RMSEA, SRMR, PGFI, NFI ve PNFI'nın ise kabul edilebilir uyum gösterdikleri söylenebilir. GFI değeri ise beklenenden düşük çıkmıştır. Diğer indeks değerlerinin mükemmel veya kabul edilebilir düzeyde uyum ölçütleri içinde yer alması ve bu indeks değerinin kabul edilebilir uyum ölçütüne yakın olması nedeniyle DFA'da incelenen altı faktörlü modelin veriye yeterli düzeyde uyum sağladığı söylenir.

Tablo 4. DFA Sonucu Elde Edilen Uyum İndeksi Değerleri ve Bu İndekslerin Mükemmel ve Kabul Edilebilir Uyum Ölçütleri

\begin{tabular}{lccc}
\hline $\begin{array}{l}\text { Ele alınan uyum } \\
\text { indeksleri }\end{array}$ & $\begin{array}{c}\text { Elde edilen uyum } \\
\text { değerleri }\end{array}$ & $\begin{array}{c}\text { Mükemmel uyum } \\
\text { ölçütleri }\end{array}$ & $\begin{array}{c}\text { Kabul edilebilir uyum } \\
\text { ölçütleri }\end{array}$ \\
\hline$\chi^{2} / \mathrm{sd}$ & $481.64 / 260=1.85$ & $0 \leq \chi^{2} / \mathrm{sd} \leq 2$ & $2 \leq \chi^{2} / \mathrm{sd} \leq 3$ \\
RMSEA & .06 & $.00 \leq \mathrm{RMSEA} \leq .05$ & $.05 \leq \mathrm{RMSEA} \leq .08$ \\
{$[90 \% \mathrm{GA}]$} & {$[.05, .07]$} & $.00 \leq \mathrm{SRMR} \leq .05$ & $.05 \leq \mathrm{SRMR} \leq .10$ \\
SRMR & .06 & $.95 \leq \mathrm{GFI} \leq 1.00$ & $.90 \leq \mathrm{GFI} \leq 95$ \\
GFI & .83 & $.95 \leq \mathrm{PGFI} \leq 1.00$ & $.50 \leq \mathrm{PGFI} \leq 95$ \\
PGFI & .67 & $.95 \leq \mathrm{CFI} \leq 1.00$ & $.90 \leq \mathrm{CFI} \leq .95$ \\
CFI & .97 & $.95 \leq \mathrm{NNFI} \leq 1.00$ & $.90 \leq \mathrm{NNFI} \leq .95$ \\
NNFI & .97 & $.95 \leq \mathrm{NFI} \leq 1.00$ & $.90 \leq \mathrm{NFI} \leq .95$ \\
NFI & .94 & $.95 \leq \mathrm{PNFI} \leq 1.00$ & $.50 \leq \mathrm{PNFI} \leq .95$ \\
PNFI & .81 & .97 & $.90 \leq \mathrm{IFI} \leq .95$ \\
IFI & .97 & \\
\hline
\end{tabular}

DFA sonucu maddelere ilişkin $t$ değerleri Tablo 5 'te verilmiştir. Tablo 5 'ten maddelerin $t$ değerlerinin 5.85 ile 17.63 arasında değiştiği görülmektedir. Buradan maddelerin $t$ değerlerinin .01 düzeyinde anlamlı olduğu söylenebilir. Çalışmada anlamsız $t$ değerine sahip hiçbir madde bulunmadığı ve model veriye yeterli düzeyde uyum sağladığı için değişimleme (modification) yapılmamıştır.

Tablo 5. DFA Analizi Sonucun Elde Edilen Maddelere Ait $t$ Değerleri

\begin{tabular}{cccccccc}
\hline Madde & $t$ & Madde & $t$ & Madde & $t$ & Madde & $t$ \\
\hline $\mathrm{m} 40$ & $6.61^{*}$ & $\mathrm{~m} 18$ & $15.73^{*}$ & $\mathrm{~m} 19$ & $13.24^{*}$ & $\mathrm{~m} 37$ & $5.85^{*}$ \\
$\mathrm{~m} 41$ & $8.92^{*}$ & $\mathrm{~m} 22$ & $10.27^{*}$ & $\mathrm{~m} 20$ & $8.65^{*}$ & $\mathrm{~m} 34$ & $9.29^{*}$ \\
$\mathrm{~m} 42$ & $6.19^{*}$ & $\mathrm{~m} 31$ & $12.95^{*}$ & $\mathrm{~m} 49$ & $12.54^{*}$ & $\mathrm{~m} 35$ & $10.00^{*}$ \\
$\mathrm{~m} 45$ & $6.17^{*}$ & $\mathrm{~m} 33$ & $14.83^{*}$ & $\mathrm{~m} 50$ & $16.36^{*}$ & $\mathrm{~m} 36$ & $11.87^{*}$ \\
$\mathrm{~m} 48$ & $14.05^{*}$ & $\mathrm{~m} 12$ & $13.71^{*}$ & $\mathrm{~m} 51$ & $12.27^{*}$ & & \\
$\mathrm{~m} 16$ & $12.32^{*}$ & $\mathrm{~m} 13$ & $11.41^{*}$ & $\mathrm{~m} 25$ & $10.44^{*}$ & & \\
$\mathrm{~m} 17$ & $16.02^{*}$ & $\mathrm{~m} 15$ & $17.63^{*}$ & $\mathrm{~m} 32$ & $11.09^{*}$ & & \\
${ }^{*} \mathrm{P}<.01$ & & & & & & &
\end{tabular}

Altı faktörlü ölçüm modeli Şekil 2'de verilmiştir. Faktörlere ait madde yüklerinin "Mekân Yeterliği”" faktöründe .55 ile .81 arasında, "Kişisel Gelişim" faktöründe .54 ile .78 arasında, "Toplumsal Değer Bilinci" faktöründe .55 ile .63 arasında, "Mekân Çekiciliği" faktöründe .53 ile .65 arasında, "Teknolojik Destek" faktöründe .39 ile .74 arasında ve "Spor ve Sanat Desteği” faktöründe ise .66 ile .76 arasında değiştiği belirlenmiştir. 


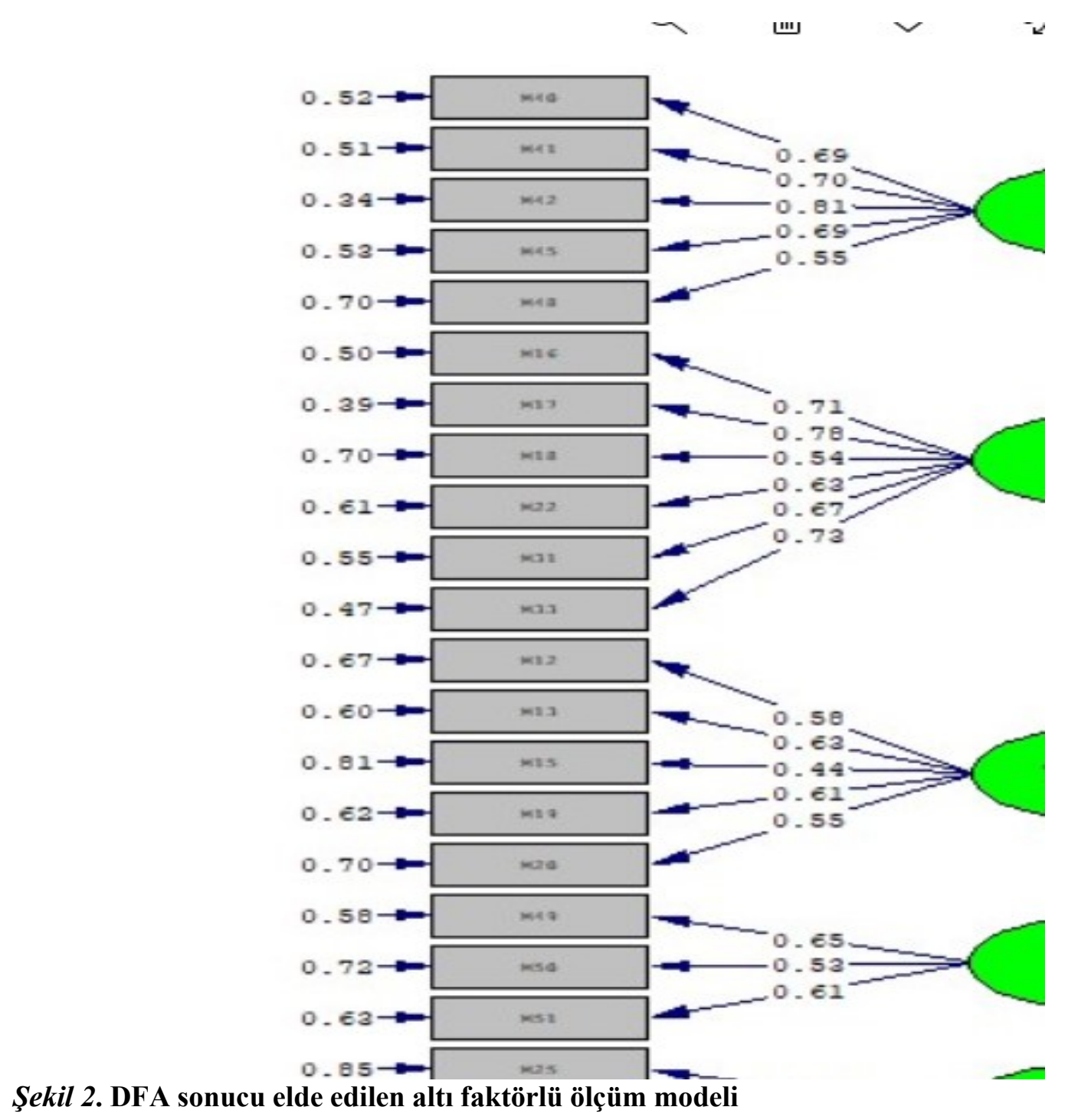

\section{Güvenirlik Kanıtları}

Ölçümlerin güvenirlik kanıtlarını elde etmek için AFA verilerinden her bir faktörün Cronbach Alfa $(\alpha)$ katsayısı, ölçeğin geneli için tabakalanmış alfa katsayısı; DFA verilerinden ise bileşik (composite) güvenirlik katsayısı hesaplanmıştır. İlgili istatistikler Tablo 6'da verilmiştir.

Tablo 6. Faktörler ve Ölçeğin Geneline İlişkin Cronbach Alfa, Tabakalanmış Alfa ve Bileşik Güvenirlik Katsayıları

\begin{tabular}{lcc}
\hline Faktörler & Alfa $(\alpha)$ & Bileşik Güvenirlik \\
\hline 1. Mekân Yeterliği & 0.85 & 0.82 \\
2. Kişisel Gelişim & 0.88 & 0.84 \\
3. Toplumsal Değer Bilinci & 0.84 & 0.70 \\
4. Mekân Çekiciliği & 0.79 & 0.62 \\
5. Teknolojik Destek & 0.73 & 0.53 \\
6. Spor ve Sanat Desteği & 0.74 & 0.76 \\
\hline Genel & 0.94 & 0.94 \\
\hline
\end{tabular}


Tablo 6'dan ölçeğin geneline ilişkin her iki güvenirlik katsayısının yüksek ve aynı (.94) iken bu katsayıların faktörlerde değiştiği görünmektedir. Cronbach Alfa katsayıları .73 ile .88 arasında değişirken, bileşik güvenirlik katsayılarının .53 ile .84 arasında değişmektedir. Tablo 6'dan "Mekân Çekiciliği” ile "Teknolojik Destek" faktörlerinde her iki güvenirlik katsayılarının birbirlerinden oldukça farklılaştıkları belirlenmiştir. Bunun nedeni bileşik güvenirlik katsayısının madde faktör yükleri ve ölçüm hatalarına dayalı olarak hesaplanmasıdır. Şekil 2'den görüleceği üzere bu faktörlerdeki maddelerin ölçüm hataları diğer faktörlerdeki madde ölçüm hataları ile benzerlik gösterirken; diğer faktörlerdeki maddelere göre maddelerin faktör yükleri düşük kalmıştır. Bu nedenle hesaplanan bileşik güvenirlik katsayıları düşüktür. $\mathrm{Bu}$ faktörlerdeki maddelerin ölçüm hataları ve faktör yükleri DFA ölçütleri için uygun olduğundan bileşik güvenirlik katsayı hesaplamasına devam edilmiştir. "Mekân Çekiciliği”" ile "Teknolojik Destek" faktörlerinin dışındaki faktörlerin her iki güvenirlik katsayıları .70'in üzerindedir. Bu faktörlerin alfa katsayıları (sırasıyla .79 ve .73) ise iyi düzeyde, bileşik güvenirlik katsayıları (sırasıyla .62 ve .53) orta düzeyde bir korelasyon katsayısına sahip olduğundan ölçeğin yeterli güvenirlik katsayılarına sahip olduğu söylenir.

\section{Madde Analizi}

Maddelerin toplam puanı yordama güçleri ve ayırt edicilikleri için düzeltilmiş madde toplam korelasyonları hesaplanmış ve \%27'lik alt-üst grup karşılaştırmaları yapılmış, Tablo 7'de bu değerler özetlenmiştir. Ayrıca Tablo 7'de maddelere ait ortalama ve standart sapma değerlerine de yer verilmiştir.

Tablo 7'den düzeltilmiş madde toplam korelasyon değerlerinin pozitif olduğu görülmektedir. Bu değerlerin "Mekân Yeterliği" faktörü için .44 ile .55 arasında, "Kişisel Gelişim" faktörü için .63 ile .71 arasında, "Toplumsal Değer Bilinci” faktörü için .55 ile .63 arasında, "Mekân Çekiciliği” faktörü için .53 ile .59 arasında, "Teknolojik Destek" faktörü için .48 ile .54 arasında ve "Spor ve Sanat Desteği" faktörü için .53 ile .63 arasında olduğu görülmektedir. Maddelerin korelasyon değerlerinin .30 'dan büyük olması, onların ölçülen özelliği ölçmede yeterli ayırt ediciliğe sahip olduklarını göstermektedir. Tablo 7'de madde ortalamalarının 2.45 ile 3.36 arasında, standart sapmalarının ise 1.14 ile 1.40 arasında değiştiği görülmektedir.

Çalışmada \%27'lik alt ve üst grup karşılaştırması hem madde düzeyinde hem de faktör düzeyinde yapılmıştır. Madde puanları arasındaki farkların $t$ değerleri "Mekân Yeterliği" faktöründe 52.75 ile 65.14 arasında, "Kişisel Gelişim" faktöründe 51.42 ile 64.17 arasında, “Toplumsal Değer Bilinci” faktöründe 49.71 ile 53.33 arasında, "Mekân Çekiciliğì" faktöründe 55.40 ile 64.33 arasında, "Teknolojik Destek" faktöründe 49.85 ile 62.35 arasında ve "Spor ve Sanat Desteği" faktöründe ise 52.15 ile 87.53 arasındadır $(s d=298, p<.01)$. Bu faktörlere ait $t$ değerleri ise sirasiyla 45.27, 48.33, 47.27, 51.01, 51.05 ve 48.87' dir ( $s d=298, p<.01)$. Maddelere ve faktörlere ait $t$ değerlerinin anlamlı çıkması, ölçek maddelerinin ve faktörlerinin ölçülmek istenen özelliği ölçmede ayırt yeterli düzeyde ayırt edici olduğunu göstermektedir. 
Tablo 7. Tüm Veriden Elde Edilen Madde Analizi Sonuçları

\begin{tabular}{|c|c|c|c|c|c|c|}
\hline Faktörler & Maddeler & $\begin{array}{l}\text { Düzeltilmiş Madde } \\
\text { Toplam Korelasyonu }\end{array}$ & Ortalama & $\begin{array}{l}\text { Standart } \\
\text { Sapma }\end{array}$ & & $t$ \\
\hline \multirow[t]{5}{*}{ 1.Mekân Yeterliği } & $\mathrm{m} 40$ & $0.44^{*}$ & 3.03 & 1.40 & $65.14^{*}$ & \multirow{5}{*}{$45.27^{*}$} \\
\hline & $\mathrm{m} 41$ & $0.55^{*}$ & 2.92 & 1.35 & $62.89^{*}$ & \\
\hline & $\mathrm{m} 42$ & $0.51^{*}$ & 3.04 & 1.39 & $63.45^{*}$ & \\
\hline & $\mathrm{m} 45$ & $0.52^{*}$ & 3.36 & 1.31 & $52.75^{*}$ & \\
\hline & $\mathrm{m} 48$ & $0.54^{*}$ & 3.03 & 1.34 & $58.14^{*}$ & \\
\hline \multirow[t]{6}{*}{ 2.Kişisel Gelişim } & $\mathrm{m} 16$ & $0.66^{*}$ & 3.00 & 1.36 & $53.40^{*}$ & \multirow{6}{*}{$48.33^{*}$} \\
\hline & $\mathrm{m} 17$ & $0.66^{*}$ & 3.12 & 1.23 & $51.42^{*}$ & \\
\hline & $\mathrm{m} 18$ & $0.65^{*}$ & 2.77 & 1.23 & $59.40^{*}$ & \\
\hline & $\mathrm{m} 22$ & $0.63^{*}$ & 2.95 & 1.25 & $55.18^{*}$ & \\
\hline & $\mathrm{m} 31$ & $0.67^{*}$ & 3.09 & 1.25 & $53.10^{*}$ & \\
\hline & $\mathrm{m} 33$ & $0.71^{*}$ & 2.75 & 1.26 & $64.17^{*}$ & \\
\hline \multirow{5}{*}{$\begin{array}{l}\text { 3.Toplumsal } \\
\text { Değer Bilinci }\end{array}$} & $\mathrm{m} 12$ & $0.55^{*}$ & 3.17 & 1.26 & $52.68^{*}$ & \multirow{5}{*}{$47.27^{*}$} \\
\hline & $\mathrm{m} 13$ & $0.60^{*}$ & 2.95 & 1.22 & $51.97^{*}$ & \\
\hline & $\mathrm{m} 15$ & $0.63^{*}$ & 3.13 & 1.18 & $49.71^{*}$ & \\
\hline & m19 & $0.63^{*}$ & 3.10 & 1.18 & $53.21^{*}$ & \\
\hline & $\mathrm{m} 20$ & $0.58^{*}$ & 2.93 & 1.14 & $53.33^{*}$ & \\
\hline \multirow{3}{*}{$\begin{array}{l}\text { 4.Mekân } \\
\text { Çekiciliği }\end{array}$} & $\mathrm{m} 49$ & $0.54^{*}$ & 2.88 & 1.21 & $55.40^{*}$ & \multirow{3}{*}{$51.01^{*}$} \\
\hline & $\mathrm{m} 50$ & $0.59^{*}$ & 2.74 & 1.21 & $64,33^{*}$ & \\
\hline & $\mathrm{m} 51$ & $0.53^{*}$ & 2.74 & 1.21 & $60,81^{*}$ & \\
\hline \multirow{3}{*}{$\begin{array}{l}\text { 5.Teknolojik } \\
\text { Destek }\end{array}$} & $\mathrm{m} 25$ & $0.48^{*}$ & 2.49 & 1.24 & $52,02^{*}$ & \multirow{3}{*}{$51.05^{*}$} \\
\hline & $\mathrm{m} 32$ & $0.54^{*}$ & 2.45 & 1.23 & $49,85^{*}$ & \\
\hline & $\mathrm{m} 37$ & $0.51^{*}$ & 2.47 & 1.29 & $62.35^{*}$ & \\
\hline \multirow{3}{*}{$\begin{array}{l}\text { 6.Spor ve Sanat } \\
\text { Desteği }\end{array}$} & $\mathrm{m} 34$ & $0.57^{*}$ & 2.56 & 1.31 & $87.53^{*}$ & \multirow{3}{*}{$48.87^{*}$} \\
\hline & $\mathrm{m} 35$ & $0.53^{*}$ & 3.12 & 1.26 & $52.15^{*}$ & \\
\hline & $\mathrm{m} 36$ & $0.63^{*}$ & 2.65 & 1.22 & $56.69^{*}$ & \\
\hline
\end{tabular}

${ }^{*} p<.01 s d=298$

\section{Tartıșma, Sonuç ve Öneriler}

Bu çalışmada, öğrenci algılarına göre okul etkililiğinin belirlenmesinde geçerli ve güvenilir ölçümler sağlayacak bir ölçek geliştirilmesi amaçlanmıştır. Bu amaç doğrultusunda ilgili alan yazın taranmış, uluslararası (PISA, TIMSS) ve bireysel çalışmalarda kullanılan ölçekler incelenmiştir. Etkili okulun birçok araştırmacı tarafından kabul edilmiş değişkenleri üzerine odaklanılmıştır: Okulun açık misyonu/amacı olması, öğrenci başarısına ilişkin yüksek beklentilerin olması, öğrenmeyi kolaylaştıracak güvenli ve düzenli bir çevrenin oluşturulması ve okul iklimi. $\mathrm{Bu}$ değişkenler dikkate alınarak 53 maddeden oluşan madde havuzu oluşturulmuştur. Maddelerin görünüş geçerliği ve madde havuzunun kapsam geçerliği bir uzmandan görüş alınarak sağlanmıştır. Uzmandan gelen dönütlerin değerlendirilmesi sonucu iki madde havuzdan çıkarılmıştır. Maddelerin havuzundan çıkarıldığ 1 takdirde kapsamın daralmaması dikkate alınmıştır. Dilsel anlaşılırlık için dil bilim uzmanından görüş alınmış, 
gelen dönütler doğrultusunda ilgili düzenlemeler yapılmıştır. Sonuç olarak 51 maddeden ve "Kesinlikle katılmıyorum"dan "Kesinlikle katılıyorum"a kadar 5'li derecelendirilmiş Likert tipinde ölçeğin deneme formu oluşturulmuştur.

“Algılanan Okul Etkililiği Ölçeği” ölçümlerinden yapılan yorumların yap1 geçerliğine ilişkin kanıt toplamak için farklı örneklemler üzerinde AFA ve DFA yapılmıştır. AFA sonucunda altı faktörlü bir yapı elde edilmiştir. Madde içerikleri ve alan yazın dikkate alınarak bu faktörler sırasıyla "Mekân Yeterliği", "Kişisel Gelişimi", "Toplumsal Değer Bilinci”, "Mekân Çekiciliği", "Teknolojik Destek" ve "Spor ve Sanat Desteği”" olarak adlandırılmıştır. Bu boyutlar çalışmanın başında tahmin edilen boyutlarla birebir örtüşmemektedir. Örneğin öğrenci duyguları, okul iklimi ve öğrencilerden yüksek beklentileri ifade eden maddeler bir boyut oluşturmamıştır. $\mathrm{Bu}$ açıdan bu ölçek Türkiye'de geliştirilen Balcı'nın (2001), KasapÇobanoğlu'nun (2008) ve Günal'ın (2014) ölçeğinden farklılaşmaktadır. Öte yandan ölçekte yer alan "çevre" bileşeni Türkiye'de geliştirilen bazı ölçeklerle (Günal, 2014; Kasap-Çobanoğlu, 2008) paralellik göstermiştir. Fakat çevre bileşeni bu çalışmalardan farklı olarak iki ayrı boyutta ölçülmüştür. Bu boyutlar "Mekân yeterliği” ve "Mekân çekiciliği”dir. Mekân yeterliği boyutu bir okulun amaçlarını gerçekleştirmek için gerekli fiziki imkâna sahip olup olmadığını ifade ederken; mekân çekiciliği mekânın bakımı ve düzeni ile alakalıdır. Türkiye ve dünya alan yazınında fiziksel ortamın eğitimdeki önemi her geçen gün arttığı ifade edilmektedir (Gifford, 1997; Joint Information Systems Committee, 2006; Oblinger, 2006; Stevenson, 2006; Temple, 2007; Tor, 2015). Geliştirilen bu ölçeğin bu önemi vurguladığ görülmektedir. Bu ölçeğin geliştirilmesinde dikkate alınan bir bileşen de "okul misyonu ve amaçları"dır. Bu bileşenin ölçekte dört boyutta ölçüldüğü görülmüştür: "Kişisel Gelişim”, "Toplumsal Değer Bilinci”, “Teknolojik Destek” ve "Spor ve Sanat Desteği”"dir. Bu yönüyle bu ölçek Balcı'nın (2001), Kasap-Çobanoğlu'nun (2008) ve Günal'ın (2014) ölçeğinden farklılaşmaktadır.

Yapılan AFA sonucunda elde edilen altı faktörün toplam varyansin \%66.11'ini açıkladıkları belirlenmiştir. Açıklanan bu varyans miktarının Türkiye'de geliştirilen KasapÇobanoğlu'nun (2008) ve Günal'ın (2014) ölçeklerinde açılanan varyans miktarlarından (sırasıyla \%52,66 ve \%46.96) fazla olduğu görülmüştür. Uyarlaması yapılan ölçeklerle kıyaslandığında ise bu miktarın genel olarak diğer ölçeklerden fazla olduğu görülmüştür. Örneğin Hoy ve Sweetland'ın (2000) ölçeğini uyarlayan Buluç (2009) ölçeğin açıklanan varyansını \% 43.27 olarak tespit etmiştir. Hoy ve Ferguson'nın (1985) ölçeğini kullanan Şenel ve Buluç (2016) açıklanan varyansı \%50.052, Cerit ve Yıldırım (2017) \%75.30, Yıldırım, Akan ve Yalçın (2016) ise \%49.05 olarak hesaplamıştır.

DFA'da model veri uyumunun değerlendirilmesinde belirli indeksler ve bu indekslerin belirli ölçütleri yoktur. Bu nedenle bu çalışmada on indeksten yararlanılmıştır. Dokuz uyum indeksinin belirlenen ölçütler içerisinde yer alması nedeniyle modelin veriye yeterli düzeyde uyum sağladığı söylenebilir.

“Algılanan Okul Etkililiği Ölçeği” ölçümlerinin güvenirlik kanıtlarını elde etmek için AFA verilerinden her bir faktörün Cronbach Alfa $(\alpha)$ katsayısı ve ölçeğin geneli için tabakalanmış alfa katsayısı hesaplanmışır. Ayrıca DFA verilerinden bileşik (composite) güvenirlik katsayısı hesaplanmıştır. Ölçeğin geneline ilişkin güvenirlik katsayılarının (tabakalanmış alfa ve bileşik güvenirlik katsayısı) yüksek ve aynı olduğu (.94) görülmüştür. Bu güvenirlik katsayıları alan yazındaki diğer ölçeklerle benzerlik göstermektedir. Türkiye'de 
geliştirilen Kasap-Çobanoğlu'nun (2008) ve Günal'ın (2014) ölçeklerinde hesaplanan güvenirlik katsayıları sırasıyla $\alpha=.97$ ve $\alpha=.91$ 'dir. Benzer şekilde Hoy ve Sweetland'ın (2000) ölçeğini uyarlayan Buluç (2009) ölçeğin güvenirliğini $\alpha=.88$ olarak tespit etmiştir. Hoy ve Ferguson'nın (1985) ölçeğini kullanan Şenel ve Buluç (2016) güvenirliğini $\alpha=.86$, Cerit ve Yıldırım (2017) $\alpha=.89$, Yıldırım, Akan ve Yalçın (2016) ise $\alpha=.87$ olarak hesaplamıştır.

Madde geçerlik kanıtlarını elde etmek, başka bir ifade ile madde ayırt ediciliğini incelemek için düzeltilmiş madde toplam korelasyonu hesaplanmış ve \%27'lik alt-üst grup karşılaştırmaları yapılmıştır. Hesaplamalar sonucunda maddelerin düzeltilmiş madde toplam korelasyonlarının pozitif ve .44 ile .71 arasında değiştiği görülmüştür. Yapılan alt-üst grup karşılaştırmaları sonucunda ise tüm maddelerin $t$ değerlerinin istatistiksel olarak anlamlı olduğu belirlenmiştir. Tüm maddelerin düzeltilmiş madde toplam korelasyonlarının yüksek ve $t$ değerlerinin istatistiksel olarak anlamlı bulunması onların ölçülen yapıyı ölçmede ayırt edici olduklarını göstermektedir.

Bilindiği üzere geçerlik bir ölçme aracından elde edilen ölçümlere dayalı olarak yapılan yorumlarla, güvenirlik ise ölçümlerle ilişkilidir (Bademci, 2013). Bu çalışma Anadolu ve Mesleki ve Teknik Lise öğrencilerinden elde edilen veriler ile gerçekleştirilmiştir. Bu nedenle bu ölçeğin farklı türdeki örneklemlerde uygulandığında geçerlik ve güvenirlik kanıtlarının tekrar elde edilmesi önemlidir. Ayrıca geliştirilen bu ölçek farklı çalışmalarda kullanılarak yaygınlaştırılmalı, geçerlik ve güvenirlik kanıtları zenginleştirilmelidir.

Algılanan Okul Etkililiği Ölçeği’nin Gelişstirilmesi: Geçerlik ve Güvenirlik Çalışması başlıklı çalışmanın yazım sürecinde bilimsel, etik ve alıntı kurallarına uyulmuş; toplanan veriler üzerinde herhangi bir tahrifat yapılmamış, karşılaşılacak tüm etik ihlallerde "Pamukkale Üniversitesi Eğitim Fakültesi Dergisi Yayın Kurulunun" hiçbir sorumluluğunun olmadığı, tüm sorumluluğun Sorumlu Yazara ait olduğu ve bu çalışmanın herhangi başka bir akademik yayın ortamına değerlendirme için gönderilmemiş olduğunu taahhüt ederim. 


\section{Kaynakça}

Alanoğlu, M. (2014). Ortaöğretim kurumlarının örgütsel ögrenme düzeylerinin okul etkililiği ve örgütsel vatandaşlık davranışlarına etkisi (Yayınlanmamış yüksek lisans tezi). Fırat Üniversitesi, Elazı̆̆g.

Akan, D. (2007). Değişim sürecinde ilköğretim okullarının etkili okul özelliklerine sahip olma düzeyleri: Erzurum ili örneği (Yayımlanmamış doktora tezi). Erzurum Üniversitesi, Erzurum.

Aksu, A. (1994). Okul müdürlerinin etkililiği ve okul iklimi (Yayınlanmamış doktora tezi). İnönü Üniversitesi, Malatya.

Arslan, H., Satıcı, A., ve Kuru, M. (2007). Resmi ve özel ilköğretim okullarının kültür ve etkililik düzeylerinin karşlaştırılması. Kuram ve Uygulamada Eğitim Yönetimi, 51, 371

Bademci, V. (2013). Değerbiçiciler arası (interrater) ölçüm güvenirliğinin Cronbach'ın alfası ile kestirilmesi. Gazi Üniversitesi Endüstriyel Sanatlar Ĕ̈itim Fakültesi Dergisi, 30, 55-62.

Balcı, A. (2002). Etkili okul geliştirme. Ankara: Pegema Yayıncılık.

Balc1, İ. (2001). İlköğretim okulu yöneticilerinin duygusal zeka becerilerini kullanabilme düzeyleri konusunda yöneticilerin ve ögretmenlerin görüşleri (Yayınlanmamış yüksek lisans tezi). Hacettepe Üniversitesi Sosyal Bilimler Enstitüsü, Ankara.

Barnard, C.I. (1948). Organization and management: Selected papers. Cambridge, MA: Harvard University Press.

Baştepe, İ. (2002). Normal ve taşımalı eğitim yapan resmi ilköğretim okul yönetici, öğretmen ve sekizinci sinıf ögrencilerinin okul (örgütsel) etkililik algıları (Yayınlanmamıs doktora tezi). Ankara Üniversitesi Sosyal Bilimler Enstitüsü, Ankara.

Bentler, P. M., \& Bonett, D. G. (1980). Significance tests and goodness of fit in the analysis of covariance structures. Psychological Bulletin, 88(3), 588-606.

Brookover, W. (1985). Can we make schools effective for minority students. Journal of Negro Education, 54(3), 257-268.

Brookover, W., Beady, C., Flood, P., Schweitzer, J., \& Wisenbaker, J. (1979). School social systems and student achievement: Schools can make a difference. New York: Praeger.

Brookover, W.B., \& Lezotte, W. (1978). Changes in school characteristics coincident with changes in student achievement. Michigan: Michigan State University.

Buluç, B. (2009). İlköğretim okullarında bürokratik okul yapısı ile okul müdürlerinin liderlik stilleri arasındaki ilişki. Eğitim ve Bilim, 34(152), 71-86.

Bursalıglu, Z. (2003). Eğitim yönetiminde teori ve uygulama. Ankara: Pegem Yayınları.

Büyüköztürk, Ş. (2002). Faktör analizi: Temel kavramlar ve ölçek geliştirmede kullanımı. Kuram ve Uygulamada Ĕ̈itim Yönetimi, 32(32), 470-483.

Cerit, Y., ve Yıldırım, B. (2017). İlkokul müdürlerinin etkili liderlik davranışları ile okul etkililiği arasındaki ilişki. Bartın Üniversitesi Ĕ̈itim Fakültesi Dergisi, 6(3), 902-914.

Coleman, J. S. (1966). Equality of Educational Opportunity (COLEMAN) Study (EEOS), Ann Arbor, MI: Inter-university Consortium for Political and Social Research

Costello, A. B., \& Osborne, J. W. (2005). Best practices in exploratory factor analysis: Four recommendations for getting the most from your analysis. Practical Assessment Research \& Evaluation, 10(7), 1-9.

Crocker. L., \& Algina. J. (1986.). Introduction to classical and modern test theory. Philadelphia: Harcourt Brace Jovanovich College Publishers.

Çelikten, M. (2001). Okul yöneticilerinin problem çözme becerileri. Eğitim Yönetimi, 7(27), 297-309.

Çınar, O. (2010). Okul müdürlerinin iletişim sürecindeki etkililiği. Dumlupınar Üniversitesi Sosyal Bilimler Dergisi, 26.

Çokluk. Ö., Şekercioğlu. G., ve Büyüköztürk. Ş. (2012). Sosyal bilimler için çok değişkenli istatistik SPSS ve LISREL uygulamaları. Ankara: Pegem A.

Demirtaş, H.(1997). Etkili eğitim yöneticisi davranışları (Yayınlanmamış yüksek lisans tezi). İnönü Üniversitesi Sosyal Bilimler Enstitüsü, Malatya. 
Edmonds, R. R. (1981). Making public schools effective. Social Policy, 12, 56-60.

Edmonds, R., \& Frederikson, J. R. (1979). Search for effective schools: The identification and analysis of city schools that are instructionally effective for poor children. Cambridge, MA: Harvard University, Center for Urban Studies

Eğitim Reformu Girişimi (ERG-2015). Meslek liselerinde toplumsal cinsiyet eşitliği Ümraniye ve Şişli Mesleki ve Teknik Anadolu liseleri örneği. İstanbul: ERG, Çelikel Eğitim Vakfı ve FriedrichEbert-Stiftung.

Erkuş, A. (2012). Psikolojide ölçme ve ölçek geliştirme-1. Ankara: Pegem Akademi Yayınları.

Fabrigar, L. R., Wegener, D. T., MacCallum, R. C., \& Strahan, E. J. (1999). Evaluating the use of exploratory factor analysis in psychological research. Psychological Methods, 4(3), 272-299.

Gifford, R. (1997). Environmental psychology: Principles and practice. Boston: Allyn and Bacon.

Günal, Y. (2014). Etkili okul değişkenlerinin öğrenci başarısı ile ilişkisi ve okul hesap verebilirliği (Yayınlanmamış doktora tezi). Ankara Üniversitesi, Ankara.

Hu L.T., \& Bentler P.M. (1999). Cutoff criteria for fit indexes in covariance structure analysis: Conventional criteria versus new alternatives. Structural Equation Modeling, 6(1):1-55.

Joint Information Systems Committee (2006). Designing Spaces for Effective Learning: A Guide to 21st Century Learning Space Design, Higher Education Funding Council, England.

Kanmaz, A., ve Uyar, L. (2016). The effect of school efficiency on student achievement International Journal of Assessment Tools in Education, 3(2), 123-136.

Kaplan, F. (2008). Anadolu liselerinin etkili okul özelliklerini karşımla düzeyi: Ankara ili örneği (Yayımlanmamış yüksek lisans tezi). Gazi Üniversitesi, Ankara

Kasap-Çobanoğlu, F. (2008). İlköğretim okullarında örgütsel kimlik ve örgütsel etkililik: Denizli örneği (Yayınlanmamış doktora tezi). Hacettepe Üniversitesi, Ankara.

Keleş, B. (2006). İlköğretim okullarının etkili okul özelliklerine sahip olma dereceleri hakkında öğretmen görüşleri: Çorum ili örneği (Yayımlanmamış yüksek lisans tezi). Gazi Üniversitesi, Ankara.

Kline. P. (1994). An easy guide to factor analysis. New York: Routledge.

Kline, R. B. (2016). Principles and practice of structural equation modeling. New York: The Guilford Press.

Klopf, G., Schelden, E., \& Brennan, K. (1982). The Essentials of effectiveness: A job description for principals. Principal, 6(4), 35-38.

Koçak, F., ve Helvacı, M. A. (2011). Okul yöneticilerinin etkililiği: Uşak ili örneği. Eğitim Bilimleri Araştırmaları Dergisi, 1(1), 33-55.

Köksal, S. (1991). The relationship between school climate and school effectiveness as perceived by teachers in secondary schools (Yayımlanmamıs yüksek lisans tezi). ODTÜ Sosyal Bilimler Enstitüsü, Ankara.

Lezotte, L.W. (1991). Correlates of effective schools the first and secondary generations. Okemos, MI: Effective School Products.

Lezotte, L.W.(1993). Effective schools: A framework for increasing student achievement. In J.A. Banks \& C. A. M. Banks (eds), Multicultural education: Issues and perspective (303-316). Boston, MA: Ally and Bacon.

Jencks, C., Smith, M.S., Ackland, H., Bane, M.J., Cohen, D., Grintlis, H., Heynes, B., \& Michelson, S. (1972). Inequality. New York: Basic Books.

Marsh, H. W., Hau, K. T., Artelt, C., Baumert, J., \& Peschar, J. L. (2006). OECD's brief self-report measure of educational psychology's most useful affective constructs: Cross-cultural, psychometric comparisons across 25 countries. International Journal of Testing, 6(4), 311-360.

Meyers, L. S., Gamst, G., \& Guarino, A. J. (2006). Applied multivariate research: Design and interpretation. London: SAGE Publications.

Milli Eğitim Temel Kanunu, (1973). Resmî Gazete. Yayım Tarihi: 24.06.1973. Sayısı: 14574. Numarası: 1739. 
Mortimore, P. (1991). The nature and findings of school effectiveness in the primary sector. In Riddell, S., \& Brown, S. (Eds.), School effectiveness research: Its messages for school improvement. Edinburgh: HMSO.

Negiş-Işık, A., ve Gümüş, E. (2017). Yönetici öz-yeterliği ve okul etkililiği arasındaki ilişkinin incelenmesi. Kastamonu Eğitim Dergisi, 25(1), 419-434.

Oblinger, D. (2006). Learning spaces. Washington: EDUCAUSE.

Oral, Ş. (2005). İlköğretim okullarının etkili okul kavramı açısından değerlendirilmesi (Yayımlanmamış yüksek lisans tezi). Dicle Üniversitesi Sosyal Bilimler Enstitüsü, Diyarbakır.

Özdemir, S. (2000). Eğitimde örgütsel yenileşme. Ankara: Pegema Yayıncılık.

Özdemir, S., ve Sezgin, F. (2002). Etkili okullar ve öğretim liderliği. Manas Üniversitesi Sosyal Bilimler Dergisi, 3, 266-282.

Purkey, S., \& Smith, M. (1985). School reform. The district policy implications of the effective schools literature. The Elementary School Journal, 85, 353-389.

Reynolds, D., \& Creemers, B. (1990). School effectiveness and school improvement: A mission statement. School Effectiveness \& School Improvement, 1(1), 1-3.

Sackney, L. (1986). Practical strategies for improving school effectiveness. The Canadian School Executive, 6(4), 15-20.

Stevenson, K. R. (2006). School size and its relationship to student outcomes and school climate: A review and analysis of eight South Carolina state-wide studies. National Clearinghouse for Educational Facilities. Retrieved from http://www.ncef.org/pubs/size_outcomes.pdf

Şenel, T., ve Buluç, B. (2016). İlkokullarda okul iklimi ile okul etkililiği arasındaki ilişki. TÜBAV Bilim, 9(4), 1-12.

Şişman, M. (1996). Etkili okul yönetimi araştırma raporu. Eskişehir: Osmangazi Üniversitesi Fen Edebiyat Fakültesi.

Şişman, M. (2002). Eğitimde mükemmellik arayışı - Etkili okullar. Ankara: Pegem Yayınları.

Şişman, M. (2014). Türk eğitim sistemi ve okul yönetimi. Ankara: Pegem Akademi.

Şişman, M., ve Turan, S. (2004). Eğitimde toplam kalite yönetimi. Ankara: Pegem Akademi.

Tabachnick. B., \& Fidell. L. (2007). Using multivariate statistics. Boston: Allyn and Bacon.

Tan, Ş. (2014). Eğitimde ölçme ve değerlendirme: KPSS el kitabı. Ankara: Pegem Akademi.

Taş, H. (2007). Avrupa Birliği ve etkili okul. Çă̆daş Eğitim Dergisi, 341, 40-45.

Temple, P. (2007). Learning spaces for the 21 st century: A review of the literature. Higher Education Academy, London. Retrieved from http://www.heacademy.ac.uk/assets/documents/research/Learning_spaces_v3.pdf

Tezbaşaran, A. (2008). Likert tipi ölçek hazırlama kılavuzu. Ankara: Türk Psikologlar Derneği

Tınmaz, M. (2000). Kamu ve özel sektör ilköğretim okulu yöneticilerinin etkililiği: İstanbul İli örneği (Yayımlanmamış yüksek lisans tezi). Sakarya Üniversitesi, Sakarya.

Toprak, M. (2011). İlköğretim okullarında görev yapan öğretmenlerin okul etkililiğine iliş̧kin görüşleri: Adıyaman ili örneği (Yayınlanmamış yüksek lisans tezi). Fırat Üniversitesi, Elazı̆̆.

Tor, D. (2015). Exploring physical environment as hidden curriculum in higher education: A grounded theory study (Unpublished doctoral dissertation). Middle East Technical University, Ankara.

Tunçel, M. (2008). Genel liseler ve anadolu liselerinin etkili okul özelliklerinin karşılaştırılması: Ankara ili örneği (Yayımlanmamış yüksek lisans tezi). Gazi Üniversitesi, Ankara.

Weber, G. (1971). Inner-city children can be taught to read: Four successful schools. Washington, D.C.: Council for Basic Education.

Yelok, F. (2006). Genel liselerde görevli öğretmenlerin etkili okula ilişskin görüşleri: Ankara ili örneği (Yüksek lisans tezi). Gazi Üniversitesi Eğitim Bilimleri Enstitüsü, Ankara.

Yenipinar, Ş. (1998). İlkögretim Okulu Yöneticilerinin Ekililik Düzeyi. (Yayinlanmamis Yüksek Lisans Tezi), Bolu: izzet Baysal Üniversitesi Sosyal Bilimler Enstitüsü . 
Yıldırım, İ. (2015). Okul yöneticilerinin kişilik ve denetim odă̆ özelliklerinin öğretmenlerin iş doyumu ve okul etkililiği açısından incelenmesi (Yayınlanmamış doktora tezi). Atatürk Üniversitesi, Erzurum.

Yıldırım, İ., Akan, D., ve Yalçın, S. (2017). The relationship between the job satisfaction and school effectiveness perceptions of classroom teachers. Erzincan Üniversitesi Eğitim Fakültesi Dergisi, 19(1), 69-81.

Yılmaz, A. (2006). İlköğretim okullarında etkililik sağlanması için öğretmenlerin ailelerden beklentileri: Sakarya ili örneği (Yayımlanmamış Yüksek Lisans Tezi). Sakarya Üniversitesi Sosyal Bilimler Enstitüsü, Sakarya.

Yörük, S., ve Şahin, B. (2012). Ortaöğretim okullarının etkili okul olmasında okul müdürlerinin kültürel liderlik rolleri. Journal of Theoretical Educational Science, 5(3), 352-368. 


\section{Extended Abstract}

\section{Introduction}

Schools carry great responsibility for transferring social values to new generations. The structure of the schools, which is the most strategic unit of the education system, consists of various roles, statuses, tasks, powers and responsibilities within the school. The purpose of organizing all these elements within a certain system is to achieve the goals of school and education, and therefore to achieve more effective education and training. The general aim of education and training in the school is to ensure that students are raised as healthy and qualified individuals in the direction of the desired knowledge, skills and behavior. The studies investigating whether a school has achieved these aims are called "effective school studies". These studies have determined some dimensions of an effective school: instructional leadership, focusing on basic skills, high expectation, safe and orderly environment, continuous evaluation of student development. In order to decide whether a school is effective, developing a valid and reliable scale is important and necessary. However, there are few scales developed for high school students in the literature in Turkey. Therefore, the purpose of this study is to develop a scale that provides valid and reliable measurements in determining school effectiveness based on student perceptions.

\section{Method}

In order to develop a scale, initially the related literature was reviewed and the scales used in international (e.g. PISA and TIMSS) and individual studies were examined. Because school effectiveness is a broad concept, this study focuses on student perception, which is accepted as an important indicator of effective schools by many researchers. Then, attention was paid to the fact that the item pool represented all aspects of the dimensions considered to demonstrate school effectiveness so that the content validity of the item pool was high. In order to provide content and face validity of the scale, expert opinion was obtained. Finally, 51 items were included in the draft form of a five-point Likert scale and applied to the study group which consisted of 549 high school students in 2017-2018 academic year.

\section{Findings and Discussion}

Exploratory and confirmatory factor analyses were carried out on the obtained data in order to determine the validity of the draft form. First of all, the assumptions of the factor analyses were checked. After the contents of the items under the same factor and the literature were taken into consideration, factors were named as "Space Adequacy", "Personal Development", "Social 
Value Consciousness", "Place Attractiveness", "Technological Support" and "Sports and Art Support". The factors explained $66.11 \%$ of the total variance. Each of the first three factors explained about $13 \%$ of the total variance, while each of the latter three factors explained about $8 \%$ of the total variance. To assess the fit of the model in CFA, the indices used in this study are: $\chi 2 /$ sd, RMSEA, SRMR, GFI, CFI, NNFI, NFI, IFI, PGFI and PNFI. As a result of CFA, four indices $(\chi 2 / \mathrm{sd}, \mathrm{CFI}, \mathrm{NNFI}$ and IFI) were found to be excellent fit and five indices (RMSEA, SRMR, PGFI, NFI, PNFI) were acceptable fit. The GFI index, on the other hand, has a value outside these criteria but close to the criteria for the acceptable fit. In order to obtain evidence for the reliability of the measurements, the Cronbach's Alpha $(\alpha)$ coefficient of each factor and the stratified alpha coefficient for the overall scale were calculated from the EFA data. In addition, composite reliability coefficient was calculated from the CFA data. The overall reliability coefficients (stratified alpha and composite reliability coefficients) were found to be high and the same (.94). The Cronbach's alpha $(\alpha)$ coefficients ranged from .73 to .88, and the composite reliability coefficients ranged from .53 to .84 . These results indicated that the scale had sufficient reliability coefficients. In order to obtain evidence for the item validity, i.e. the item discrimination, the corrected item-total correlation was calculated and the $27 \%$ lowerupper group comparisons were made. As a result of the calculations, it was seen that the corrected item-total correlations were positive and ranged between .44 and .71 . As a result of the $27 \%$ lower-upper group comparisons, $t$ values of all items were found to be statistically significant. Item analyses proved that all items had high discrimination in measuring the construct.

Consequently, in the light of all these findings, it can be concluded that the "Perceived Effective School Scale" can be used as a scale that produces valid and reliable measurements in determining school effectiveness based on student perceptions. This study was conducted with data obtained from Anatolian, vocational and technical high school students. Therefore, it is important to obtain evidence for validity and reliability when this scale is applied in different types of samples. 


\begin{tabular}{|c|c|c|c|c|c|}
\hline ALGILANAN OKUL ETKİLİLİĞİ ÖLÇEĞİ & 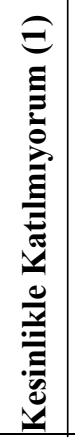 & 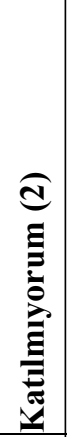 & 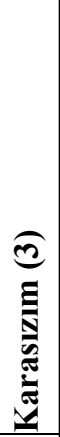 & 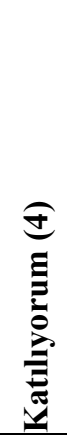 & 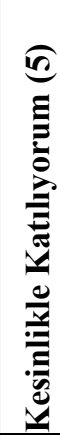 \\
\hline \multicolumn{6}{|l|}{ Mekân Yeterliği } \\
\hline spor aktiviteleri için yeterli alana sahiptir. & 1 & 2 & 3 & 4 & 5 \\
\hline sosyal etkinlikler (şenlik, vb) için yeterli alana sahiptir. & 1 & 2 & 3 & 4 & 5 \\
\hline dinlenmek için yeterli büyüklükte sınıf dışı alana sahiptir. & 1 & 2 & 3 & 4 & 5 \\
\hline etkinlikler için yeterli bahçeye sahiptir. & 1 & 2 & 3 & 4 & 5 \\
\hline bakımlı ve düzenli bir bahçeye sahiptir. & 1 & 2 & 3 & 4 & 5 \\
\hline \multicolumn{6}{|l|}{ Kişisel Gelişim } \\
\hline $\begin{array}{l}\text { bilimsel bakış açısını (neden sonuç ilişkisi kurma, eleştirel bakma, araştırma yapma, } \\
\text { vb) geliştiren bir yerdir. }\end{array}$ & 1 & 2 & 3 & 4 & 5 \\
\hline sosyal gelişimi sağlayan bir yerdir. & 1 & 2 & 3 & 4 & 5 \\
\hline yaratıcıllı̆ı geliştiren bir yerdir. & 1 & 2 & 3 & 4 & 5 \\
\hline kendimizi/kișiliğimizi tanımlamamıza yardımcı olan bir yerdir. & 1 & 2 & 3 & 4 & 5 \\
\hline bir gelişim merkezidir. & 1 & 2 & 3 & 4 & 5 \\
\hline ilgilerimizi ve meraklarımızı bulmamıza yardımcı olan bir yerdir. & 1 & 2 & 3 & 4 & 5 \\
\hline \multicolumn{6}{|l|}{ Toplumsal Değer Bilinci } \\
\hline toplumsal değerlere (sorumluluk, eşitlik, saygı, vb) önem veren bir yerdir. & 1 & 2 & 3 & 4 & 5 \\
\hline bilinçli vatandaşların (hak ve sorumluluklarını bilen ve arayan) yetiștirildiği bir yerdir. & 1 & 2 & 3 & 4 & 5 \\
\hline çevre bilincini (çevreyi koruma, vb) kazandıran bir yerdir. & 1 & 2 & 3 & 4 & 5 \\
\hline ahlaki gelişimi (dürüstlük, hoşgörü, vb) destekleyen bir yerdir. & 1 & 2 & 3 & 4 & 5 \\
\hline demokratikleşmeyi geliştiren bir yerdir. & 1 & 2 & 3 & 4 & 5 \\
\hline \multicolumn{6}{|l|}{ Mekân Çekiciliği } \\
\hline (sınıf dışı alanlar) bakımlı ve düzenlidir. & 1 & 2 & 3 & 4 & 5 \\
\hline güzel bir binaya sahiptir. & 1 & 2 & 3 & 4 & 5 \\
\hline bakımlı ve düzenli sınıflara sahiptir. & 1 & 2 & 3 & 4 & 5 \\
\hline \multicolumn{6}{|l|}{ Teknolojik Destek } \\
\hline teknoloji kullanma becerisinin gelişmesini destekleyen bir yerdir. & 1 & 2 & 3 & 4 & 5 \\
\hline öğrencilerin teknolojiyi etkin kullanmalarını destekleyen bir yerdir. & 1 & 2 & 3 & 4 & 5 \\
\hline $\begin{array}{l}\text { bilgi iletişim araçlarına (bilgisayar, programlar, internet vd.) rahatça ulaşmamızı } \\
\text { sağlayan bir yerdir. }\end{array}$ & 1 & 2 & 3 & 4 & 5 \\
\hline \multicolumn{6}{|l|}{ Spor ve Sanat Desteği } \\
\hline yeteneklerimize göre ödüllendirildiğimiz bir yerdir. & 1 & 2 & 3 & 4 & 5 \\
\hline sporda başarılı olmayı destekleyen bir yerdir. & 1 & 2 & 3 & 4 & 5 \\
\hline sanatta başarılı olmayı destekleyen bir yerdir. & 1 & 2 & 3 & 4 & 5 \\
\hline
\end{tabular}

